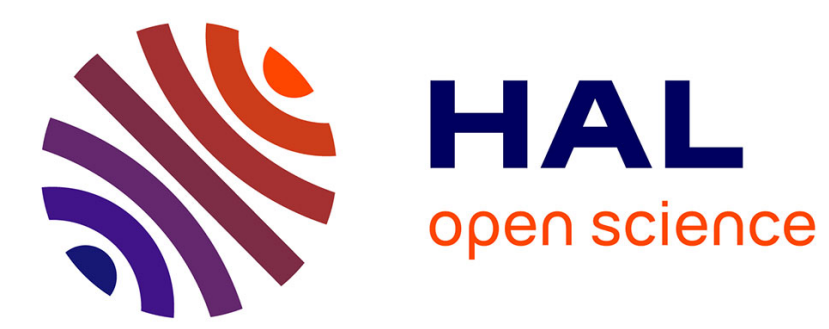

\title{
Temperatures at the base of the Laurentide Ice Sheet inferred from borehole temperature data
}

\author{
Frédérique Rolandone, J.C. Mareschal, C. Jaupart
}

\section{To cite this version:}

Frédérique Rolandone, J.C. Mareschal, C. Jaupart. Temperatures at the base of the Laurentide Ice Sheet inferred from borehole temperature data. Geophysical Research Letters, 2003, 30 (18), pp.1944. 10.1029/2003GL018046 . hal-00067834

\section{HAL Id: hal-00067834 \\ https://hal.science/hal-00067834}

Submitted on 29 Jan 2021

HAL is a multi-disciplinary open access archive for the deposit and dissemination of scientific research documents, whether they are published or not. The documents may come from teaching and research institutions in France or abroad, or from public or private research centers.
L'archive ouverte pluridisciplinaire HAL, est destinée au dépôt et à la diffusion de documents scientifiques de niveau recherche, publiés ou non, émanant des établissements d'enseignement et de recherche français ou étrangers, des laboratoires publics ou privés. 


\title{
Temperatures at the base of the Laurentide Ice Sheet inferred from borehole temperature data
}

\author{
Frédérique Rolandone, ${ }^{1}$ Jean-Claude Mareschal, ${ }^{2}$ and Claude Jaupart ${ }^{3}$ \\ Received 24 June 2003; revised 6 August 2003; accepted 14 August 2003; published 23 September 2003.
}

[1] We use temperature profiles from 4 deep $(>1600 \mathrm{~m})$ boreholes across Canada to determine ground surface temperature histories (GSTH's) through and after the Last Glacial Maximum (LGM). Inversion yields the temperature history at the base of the glacier and the surface temperature evolution after the glacial retreat. The results indicate geographic differences in basal temperature history across the Ice Sheet. During the Last Glacial Maximum, temperatures at the base of the Ice Sheet were lower in eastern Canada, at the southeastern edge of the glacier, than in central Canada, southwest of the glacier center. At all sites, basal temperatures were above the melting point of ice during and after the LGM, which may explain the highly unstable character of the Ice Sheet. The GSTH's are consistent with information on the history of the Laurentide ice sheet and provide quantitative constraints on glacier flow dynamics. INDEX TERMS: 8130 Tectonophysics: Heat generation and transport; 1827 Hydrology: Glaciology (1863); 1620 Global Change: Climate dynamics (3309). Citation: Rolandone, F., J.-C. Mareschal, and C. Jaupart, Temperatures at the base of the Laurentide Ice Sheet inferred from borehole temperature data, Geophys. Res. Lett., 30(18), 1944, doi:10.1029/2003GL018046, 2003.

\section{Introduction}

[2] Modeling the dynamics of glacial growth and retreat requires knowledge of the boundary conditions at the base of the ice sheet, which have a strong impact on basal temperature [Huybrechts, 1986; Licciardi et al., 1988; Marshall et al., 2000]. Such models are of special importance for understanding catastrophic meltwater discharges from the Laurentide Ice Sheet that may have been responsible for climatic instability and for Heinrich events [Payne, 1995; Clark et al., 2001]. The lack of subglacial paleotemperature records has led to searches for proxies [Kleman and Hattestrand, 1999].

[3] Temporal changes in ground surface temperature propagate in the solid rock basement and are recorded as perturbation of the steady-state temperature profile. It is therefore possible to determine the ground surface temperature history by inversion of vertical temperature profiles measured in boreholes [Vasseur et al., 1983; Shen and Beck, 1992; Mareschal and Beltrami, 1992]. Several

\footnotetext{
${ }^{1}$ Berkeley Seismological Laboratory, UC Berkeley, USA.

${ }^{2}$ GEOTOP-UQAM-McGill, Centre de Recherche en Géochimie et en Géodynamique, Université du Québec à Montréal, Canada.

${ }^{3}$ Institut de Physique du Globe de Paris, France.
}

Copyright 2003 by the American Geophysical Union. 0094-8276/03/2003GL018046 studies have shown that borehole data lead to reliable inferences on climatic changes over the last millenium [Lewis, 1992]. Here, we use deep boreholes to go further back in time. In order to detect the cold period of the last glacial maximum (LGM) and subsequent warming, we need temperature profiles deeper than $1,500 \mathrm{~m}$. So far, two studies of temperature profiles have yielded information on the thermal conditions at the base of the ice sheet in Canada. Sass et al. [1971] used a deep borehole $(2865 \mathrm{~m})$ near Flin-Flon, Manitoba, to show that, during the LGM, surface temperature was less than $5 \mathrm{~K}$ colder than present. They did not invert the temperature profile for detailed reconstruction of the GSTH. Mareschal et al. [2000a] used a deep (1800 m) hole near Sept-Iles, Quebec, to show that ground surface temperature during the LGM was $\approx 10 \mathrm{~K}$ colder than present. A very recent statistical study of heat flow variations in deep boreholes in the Fennoscandian Shield and the Russian platform suggests that, during the LGM, temperatures were $8 \mathrm{~K}$ colder than at present in ice free regions but that there was less cooling in ice covered regions [Kukkonen and Joeleht, 2003]. To study conditions beneath the Laurentide ice sheet, we revisit the Sept-Iles and Flin-Flon profiles and add data from 2 other deep boreholes in central Canada: one $(1725 \mathrm{~m})$ in Balmertown, northwestern Ontario, and one $(1610 \mathrm{~m})$ near Thompson, Manitoba. The location of these sites in relation to the Laurentian glacier is shown in Figure 1.

\section{Borehole Temperature Data Used in This Study}

[4] For analysis, the critical assumption is that of purely vertical conductive heat transport in the rock underlying the ice sheet. Local perturbations due to groundwater flow in fractures or heat refraction effects across media of contrasting thermal properties must therefore be avoided. The data for this study were collected during extensive heat flow surveys of the Canadian Shield [Mareschal et al., 2000b; Rolandone et al., 2002, 2003]. Because several boreholes were logged at each site, thermal conditions in the vicinity of these deep boreholes are well controlled.

[5] Figure 2 shows the thermal conductivity and the variation in heat flow with depth for the profiles. The $1800 \mathrm{~m}$ Sept-Iles borehole was drilled in a massive gabbro intrusion without conductivity variation with depth. While the lithology may be more complicated at the three other sites, the only site with systematic conductivity variation is Flin-Flon where the conductivity decreases below $1800 \mathrm{~m}$ [Sass et al., 1971], which was accounted for when determining the heat flow profile. For the other three sites, we 

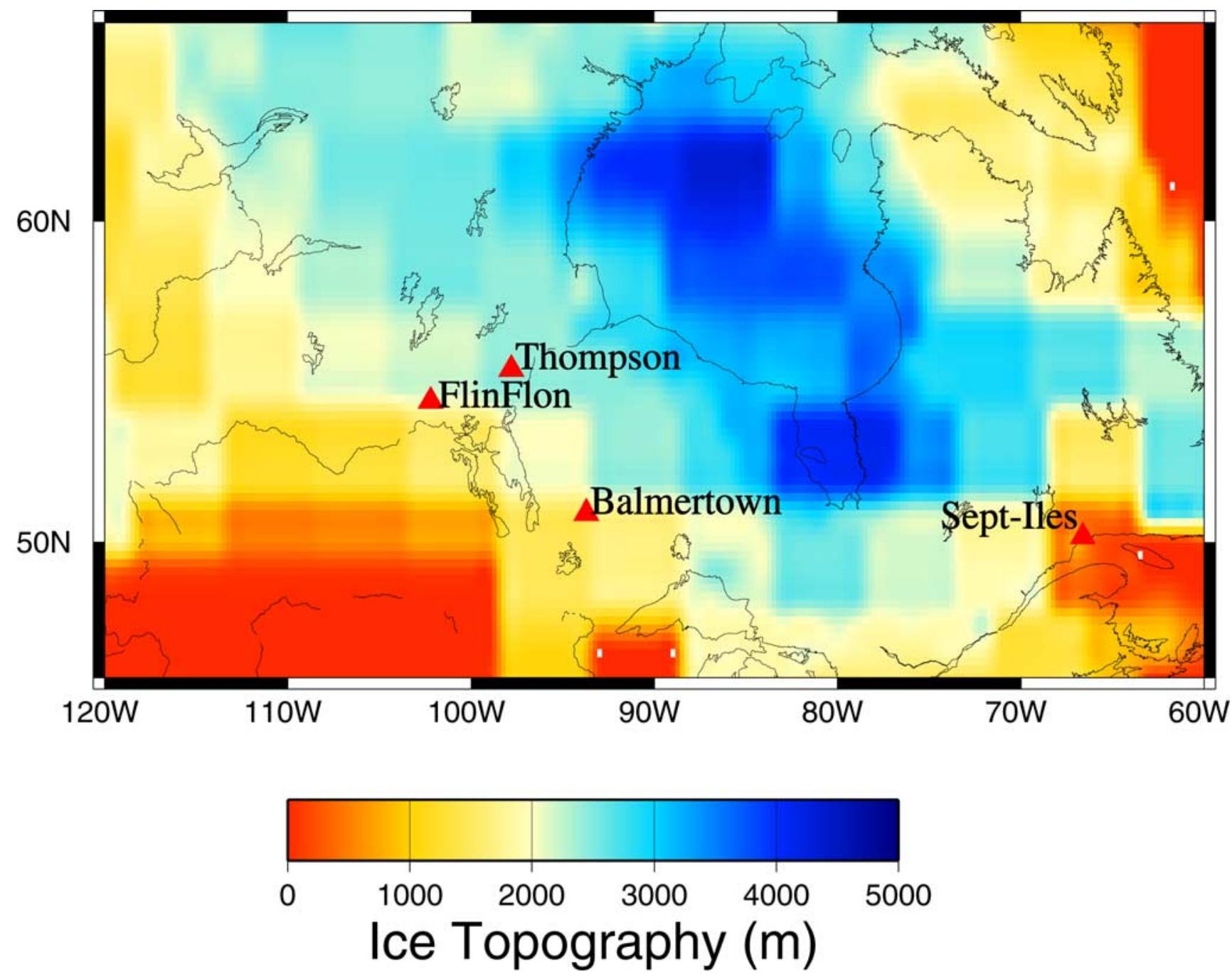

Figure 1. Ice thickness of the Laurentide glacier at $21 \mathrm{ka}$. Ice thickness model ICE-4G from Peltier [2002]. Red triangles mark the location of the deep drillholes used in this study.

have used the average thermal conductivity to determine the heat flow profile.

\section{Inversion Results}

[6] The temperature at depth $z$ in a borehole is written as:

$$
T(z)=T_{r e f}+Q_{r e f} \int_{0}^{z} \frac{d z^{\prime}}{k\left(z^{\prime}\right)}+T_{t}(z)
$$

where $T_{\text {ref }}$ is the reference ground surface temperature in the absence of perturbations, $Q_{\text {ref }}$ the steady-state heat flux from depth, $k(z)$ thermal conductivity and $T_{t}(z)$ the timedependent temperature field due to ground surface temperature changes. Heat production can be included in the analysis [Clauser and Mareschal, 1995] but it was found to be small at all the boreholes used and thus neglected for this study. For each site, we have inverted the temperature profile to determine the GSTH. The ground temperature history is approximated by a function that varies in a stepwise manner between intervals within which it remains constant. Because we are considering a long history, we have used a logarithmic distribution for the duration of the time intervals that become larger as time increases. This parameterization yields a system of equations for the temperatures during each interval and for the reference heat flow and surface temperature. This linear system of equations is ill-conditioned. Following Mareschal and Beltrami [1992], we have stabilized its solution with an inversion algorithm based on the singular value decomposition [Lanczos, 1961]. The instability is avoided by replacing the inverse of the singular values $1 / \lambda$ by $\lambda /\left(\lambda^{2}+\epsilon\right)$ where the value of $\epsilon$ depends on the noise level. This stabilization is obtained by decreasing the resolution: in practice, for an event to be resolved, its duration must be $>1 / 4$ the time it occurred [Beltrami and Mareschal, 1995]. In order to have comparable resolution, we have used the same value $\epsilon=0.08$ for all profiles. Monte-Carlo inversions [Mareschal et al., 2000a] have also been applied with similar results and suggest that the uncertainty in the paleotemperature results is about $\pm 1 \mathrm{~K}$.

[7] Table 1 lists the relevant parameters including the minimum ground surface temperature during the LGM, $T_{m i n}$, and the time interval when it was reached. The ground 


\section{ROLANDONE ET AL.: TEMPERATURES AT THE BASE OF THE LAURENTIDE $\quad$ CRY $\mathbf{3}$ - 3}
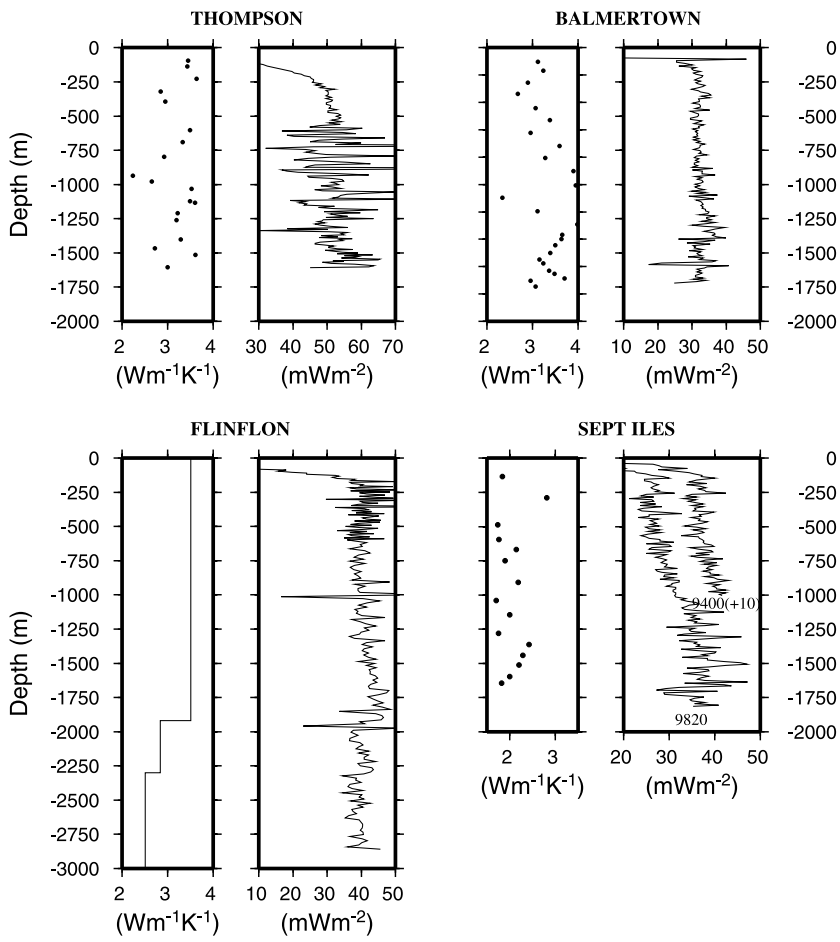

Figure 2. Thermal conductivity, and heat flow for the four deep temperature depth profiles used in this study. Conductivity measurements for Sept-Iles, Balmertown, and Thompson were made on core samples with the divided bar. Conductivity measurements at Flin-Flon were made with the needle probe and the conductivity profile represents the average from many measurements.

surface temperature histories of the four sites are shown on Figure 3.

[8] The Flin-Flon drill hole is deeper and should give better constraints than the others for events occurring between 10 to 100 kyears B.P. Three profiles show the same temperature trends, with a minimum at ca. 10,00020,000 years, followed by a warming episode peaking at ca. $3,000-4,000$ years and one cooling episode peaking a few hundred years ago. The amplitudes, however, are different. The total amplitude of the ground surface temperature variation at Sept-Iles is more than twice that at Flin-Flon. The amplitude is small at Thompson and Balmertown. There is not much difference in model resolution between Sept-Iles, Thompson, and Balmertown. The resolution difference might explain why the amplitudes of the Balmertown and Thompson GSTH's are lower than at Flin-Flon, but cannot account for the amplitude difference between Sept-Iles and Flin-Flon. If anything, Sept-Iles might have an even larger amplitude than indicated in Figure 3, as shown

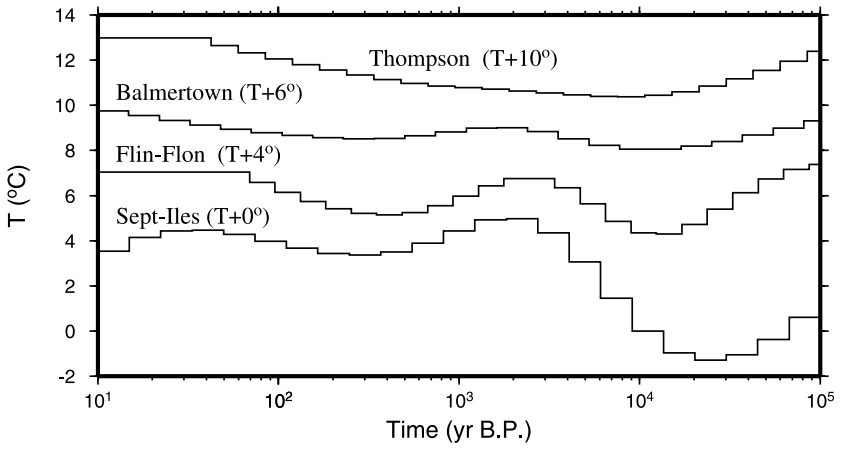

Figure 3. Ground surface temperature history inverted from borehole temperature profiles for the period $100 \mathrm{ka}$ to present. Temperature shifted as indicated. The same value of the regularization parameter $\epsilon=0.08$ was used for the four inversions.

by the slightly lower LGM temperature estimates deduced from a Monte-Carlo inversion [Mareschal et al., 2000a].

[9] The minimum temperatures were reached at different times around the LGM (21 ka) when the ice thickness was maximum. A warming episode is recorded at the 4 sites which may be attributed to ice retreat. The warming at SeptIles seems to have started between 20 and 15,000 years B.P., while it started betwen 10 and 8,000 years B.P. at Flin-Flon. Despite the low amplitude of temperature variations in Balmertown and Thompson, the GSTH's at these two sites also suggests that ground surface temperature warming started later than at Sept-Iles. These GST histories are consistent with information on the history of the Laurentide ice sheet. Reconstructions of the Laurentide Ice Sheet indicate that the Sept-Iles and Flin-Flon sites became free of ice at $c a .14,000$ and 11,500 years B.P. respectively [Licciardi et al., 1998; Dyke and Prest, 1982]. Massive meltwater discharge from the mid-continent lobes of the Laurentide Ice Sheet is recorded between 9,000 and 8,500 years in Lake Winnipeg and Lake Michigan sediments [Moore et al., 2000].

\section{Discussion}

[10] Although much colder temperatures at the base of the ice sheet are predicted by some models of ice dynamics [Marshall and Clark, 2002], it does not come as a surprise that there were spatial variations in temperature at the base of the Laurentide ice sheet. Present bedrock temperatures measured beneath the central part of the Greenland ice sheet are -8 and $-13^{\circ} \mathrm{C}$ [Dahl-Jensen et al., 1998]. Temperatures are higher in areas where basal melts have been detected [Fahnestock et al., 2001]. In Antarctica, temperatures near $0^{\circ} \mathrm{C}$ were measured at the base of the fast moving ice stream

Table 1. Temperature Depth Profiles Used in This Study

\begin{tabular}{lccccccc}
\hline \multicolumn{1}{c}{ Site } & Latitude deg min & Longitude deg min & Depth m & $T_{\text {ref }}{ }^{\circ} \mathrm{C}$ & $Q_{\text {ref }} \mathrm{mWm}^{-2}$ & $T_{\min }{ }^{\circ} \mathrm{C}$ & Time kyears BP \\
\hline Sept-Iles (QC) & $50^{\circ} 13^{\prime} \mathrm{N}$ & $66^{\circ} 38^{\prime} \mathrm{W}$ & $1810 \mathrm{~m}$ & 2.1 & 34 & -1.5 & $20-30$ \\
Balmertown (ON) & $51^{\circ} 02^{\prime} \mathrm{N}$ & $93^{\circ} 43^{\prime} \mathrm{W}$ & $1725 \mathrm{~m}$ & 3.5 & 35 & 2.1 & $8-15$ \\
Flin-Flon (SK) & $54^{\circ} 93^{\prime} \mathrm{N}$ & $102^{\circ} 00^{\prime} \mathrm{W}$ & $2865 \mathrm{~m}$ & 3.4 & 42 & 0.4 & $10-20$ \\
Pipe Mine, Thompson (MB) & $55^{\circ} 29^{\prime} \mathrm{N}$ & $98^{\circ} 08^{\prime} \mathrm{W}$ & $1610 \mathrm{~m}$ & 2.4 & 51 & 0.4 & $8-12$ \\
\hline
\end{tabular}

The table gives the geographic location, the depth of the borehole, the reference ground surface temperature, the reference heat flow, the minimum temperature recorded during the last glaciation, and the time when it occurred. 
at holes B, C, and D [Engelhardt and Kamb, 1993; Parizek et al., 2002]. Temperature at the base of the glacier depends much on the accumulation and flow of ice as well as on the geothermal heat flux. Sept-Iles is closer to the edge of the ice-sheet than the other sites and more rapid flow of ice may have resulted in colder conditions at the base. Also, SeptIles has the lowest heat flux of all these sites $\left(51 \mathrm{mWm}^{-2}\right.$ at Thompson vs $34 \mathrm{mWm}^{-2}$ at Sept-Iles), which may also partly account for the GSTH difference between these two sites. Such control of heat flow on glacier dynamics is suggested by the study of Tarasov and Peltier [2003].

[11] These results have implications for Ice Sheet models which depend on several poorly constrained parameters and processes, such as climatic changes, geographical distribution of snow fall and basal mechanical boundary conditions. For example, depending on the behaviour of basal till and ice bed, the Laurentide Ice Sheet may have developed multiple ice domes [Licciardi et al., 1998]. As emphasized by Marshall et al. [2000], there are large differences in the predicted basal temperatures between models. Our results may thus provide useful constraints on the boundary conditions. Our data show that, along its southern margin, the Laurentide Ice Sheet was not frozen to the bed, implying basal sliding. It is well-established that such conditions lead to an unstable ice sheet with limit cycles in the basal thermal regime and sliding velocity [Payne, 1995].

[12] Acknowledgments. Shawn Marshall, Dick Peltier, and John Sass provided much useful information. We are grateful to an anonymous reviewer for drawing our attention to the Antarctic ice stream temperature data. This research was supported by LITHOPROBE, NSERC (Canada) and INSU (CNRS, France).

\section{References}

Beltrami, H., and J.-C. Mareschal, Resolution of ground temperature histories inverted from borehole temperature data, Global Planet. Change, 11, 57-70, 1995.

Clark, P. U., S. J. Marshall, G. K. C. Clarke, S. W. Hostetler, J. M. Licciardi, and J. T. Teller, Freshwater forcing of abrupt climate change during the last glaciation, Science, 293, 283-287, 2001

Clauser, C., and J. C. Mareschal, Ground temperature history in central Europe from borehole temperature data, Geophys. J. Int., 121, 805817, 1995.

Dahl-Jensen, D., K. Mosegaard, N. Gundestrup, G. D. Clow, S. J. Johnsen, A. W. Hansen, and N. Balling, Past temperatures directly from the Greenland ice sheet, Science, 282, 268-271, 1998.

Dyke, A. S., and V. K. Prest, Late Wisconsinian and Holocene history of the Laurentide Ice Sheet, Géographie Physique et Quaternaire, 41, 5-14, 1982.

Engelhardt, H., and B. Kamb, Vertical temperature profile of Ice Stream B, Antarctic J. US, 28, 63-66, 1993.

Fahnestock, M., W. Abdalati, I. Joughin, J. Brozena, and P. Gogineni, High geothermal heat flow, basalt melt, and the origin of rapid ice flow in central Greenland, Science, 294, 2338-2342, 2001.

Huybrechts, P., Basal temperature conditions of the Greenland ice sheet during the glacial cycles, Ann. Glaciol., 23, 226-236, 1986.

Kleman, J., and G. Hattestrand, Frozen-bed Fennoscandian and Laurentide ice sheets during the Last Glacial Maximum, Nature, 402, 63-66, 1999.
Kukkonen, I. T., and A. Jõeleht, Weichselian temperatures from geothermal heat flow data, J. Geophys. Res., 108(B3), 2163, doi:10.1029/ 2001JB001579, 2003.

Lanczos, C., Linear Differential Operators, D. Van Nostrand, Princeton, 1961.

Lewis, T., , (ed), Climatic change inferred from underground temperatures. (Global and Planetary Change Sp. Issue no. 98), 1992.

Licciardi, J. M., P. U. Clark, J. W. Jenson, and D. R. MacAyeal, Deglaciation of a soft-bedded Laurentide Ice Sheet, Quat. Sci. Rev., 17, 427-448, 1998.

Mareschal, J.-C., and H. Beltrami, Evidence for recent warming from perturbed geothermal gradients: Examples from eastern Canada, Clim. Dyn., 6, 135-143, 1992.

Mareschal, J.-C., F. Rolandone, and G. Bienfait, Heat flow variations in a deep borehole near Sept-Iles, Québec, Canada: Paleoclimatic interpretation and implications for regional heat flow estimates, Geophys. Res. Lett., 26, 2049-2052, 2000a.

Mareschal, J.-C., C. Jaupart, C. Gariépy, L. Z. Cheng, L. Guillou-Frottier, L. G. Bienfait, and R. Lapointe, Heat flow and deep thermal structure near the edge of the Canadian Shield, Can. J. Earth. Sci., 37, 399-414, 2000 b.

Marshall, S. J., and P. U. Clark, Basal temperature evolution of North American ice sheets and implications for the 100-kyr cycle, Geophys. Res. Lett., 29(24), 2214, doi:10.1029/2002GL015192, 2002.

Marshall, S. J., L. Tarasov, G. K. C. Clarke, and W. R. Peltier, Glaciological reconstruction of the Laurentide Ice Sheet: Physical processes and modelling challenges, Can. J. Earth Sci., 37, 769-793, 2000.

Moore, T. C., J. C. G. Walker, D. K. Rea, C. F. M. Lewis, L. C. K. Shane, and A. J. Smith, Younger Dryas interval and outflow from the Laurentide Ice Sheet, Paleoceanography, 15, 4-18, 2000.

Parizek, B. R., R. B. Alley, S. Anandakrishnan, and H. Conway, Subcatchment melt and long-term stability of ice stream D, West Antarctica, Geophys. Res. Lett., 29(8), 1214, doi:10.1029/2001GL014326, 2002.

Payne, A. J., Limit cycles in the basal thermal regime of ice sheets, J. Geophys. Res., 100, 4249-4263, 1995.

Peltier, W. R., Global glacial isostatic adjustment: Paleogeodetic and spacegeodetic tests of the ICE-4G(VM2) model, J. Quat. Sci., 17, 491-510, doi:10.1002/jqs. 713, 2002.

Rolandone, F., C. Jaupart, J. C. Mareschal, C. Gariépy, G. Bienfait, C. Carbonne, and R. Lapointe, Surface heat flow, crustal temperatures and mantle heat flow in the Proterozoic Trans-Hudson Orogen, Canadian Shield, J. Geophys. Res., 107(B12), 2341, doi:10.1029/2001JB000698, 2002.

Rolandone, F., J. C. Mareschal, C. Jaupart, and C. Gosselin, Heat Flow in the Western Superior Province of the Canadian Shield, Geophys. Res. Lett., 30(12), 1367, doi:10.1029/2003GL017386, 2003.

Sass, J. H., A. H. Lachenbruch, and A. M. Jessop, Uniform heat flow in a deep hole in the Canadian Shield and its paleoclimatic implications, J. Geophys. Res., 76, 8586-8596, 1971.

Shen, P. Y., and A. E. Beck, Paleoclimate change and heat flow density from temperature data in the Superior Province of the Canadian Shield, Global. Planet. Change, 98, 143-165, 1992.

Tarasov, L., and W. R. Peltier, Greenland glacial history, borehole constraints, and Eemian extent, J. Geophys. Res., 108, doi:10.1029/ 2001JB001731, 2003.

Vasseur, G., P. Bernard, J. Van de Meulebrouck, Y. Kast, and J. Jolivet, Holocene paleotemperatures deduced from geothermal measurements, Palaeogeogr. Palaeoclimatol. Palaeoecol., 43, 237-259, 1983.

F. Rolandone, Seismological Laboratory, UC Berkeley, 215 McCone Hall, Berkeley 94720,CA, USA. (frede@seismo.berkeley.edu)

J.-C. Mareschal, Geotop, UQAM, C.P. 8888,Succ. Centre-Ville, Montréal, H3C 3P8, Canada. (jcm@olympus.geotop.uqam.ca)

C. Jaupart, Institut de Physique du Globe de Paris, 4 Place Jussieu, 75252 Paris cedex 05, France. (cj@ccr.jussieu.fr) 